\title{
Removal of Heavy Metals and Dyes Using Low Cost Adsorbents from Aqueous Medium-, A Review
}

\author{
Geetha K.S* and Belagali S.L \\ DOS in Environmental Science, University of Mysore, Manasagangothri, Mysore-570006. Karnataka, India.
}

\begin{abstract}
The removal of heavy metals and dyes from waste water using low cost adsorbents is being widely used by various researchers. In recent years, the uses of various natural adsorbents have been widely used as a replacement for the current costly methods of treatment of waste water. In this review, an extensive list of recent investigations and literature has been compiled to provide information on a wide range of low cost adsorbents. Key Words: Low cost adsorbents; Aqueous medium; Natural products; Micro organisms; Waste water.
\end{abstract}

\section{Introduction:}

Water pollution due to toxic heavy metals and dyes has been a major cause of concern for chemical and environmental engineers, which is because of excessive release of pollutants into the environment, due to industrialization and urbanization $\&$ poses a great problem to the environment.

As metals are nondegradable and dyes are highly complex, these two degrade very slowly. The waste water from industries like, metal plating, mining operations, tanneries, chloralkali and radiator manufacturing, smelting, alloy industries, textile industry, dye industries effluents need the treatment. The main techniques which have been utilized to reduce the heavy metal ions content and dyes of effluents include lime precipitation, ion exchange, adsorption onto activated carbon, membrane processing and electrolytic methods.

These methods have been found to be limited. Since they often involve high capital and operational costs and may be associated with the generation of secondary waste, which are the present treatment problems. But adsorption is very cheap, effective compared to other methods. The efforts have been contributed to develop new adsorbents and improving the existing adsorbents to have alternative materials to activated carbon.

\section{Natural products as low cost adsorbents:}

Srinivasan (1988) et al., reported that, $\mathrm{pH}$ 2.5-3.0 was optimum with sulphuric acid treated rice husk for Chromium removal. Abraham (1998) et al., studied Cadmium adsorption on Montmorillonite and reported at lower $\mathrm{pH}$ and with increasing concentration of humic acid, the metal ion does not adsorb. Mall and Upadhyay(1998) reported basic dyes adsorption on fly ash mainly depend on $\mathrm{pH}$, increase in dye concentration, particle size, carbon content and agitation speed. Ajmal (1998) stated removal of Cadmium, Zinc, Nickel and Lead from aqueous solutions by Mangifera Indica which mainly depend on $\mathrm{pH}$ value and contact time and obeyed Freundlich adsorption isotherm. De and Basu(1999) reported that, increasing agitation time, carbon dosage and decreasing initial $\mathrm{pH}$ enhance the removal of direct-T, Blue- $\mathrm{R}$ from carbonized sugarcane bagasse. Baisakh and Patnaik (2002) stated, at ambient temperature condition, removal efficiency of chromium was more (70 \%) by charcoal. Kannan \& Meenakshi Sundaram (2002) reported that, Bamboo dust had higher adsorption capacity for dyes compared to Ground nut shell, Coconut shell, Rice husk and Straw. Amal raj and Srinivasa Raghavan (2002) and Suman Mor (2002) et al., reported that, removal of Chromium was maximum at lower pH and at higher dose of activated carbon. Rao (2003) et al., stated that, the removal of $\mathrm{Cr}^{6+}, \mathrm{Ni}^{2+}, \mathrm{Cu}^{2+}, \mathrm{Pb}^{2+}$ ions was more at pH 5.0-8.0. Katyal and Daga (2003) stated that, complete removal of dyes was found at $\mathrm{pH} 10$ and $1.8 \mathrm{gm} / \mathrm{L}$ of adsorbent. Kannan and Umamathi (2003) reported that, the increase in dose of activated charcoal, contact time removal of Cd(II)-EDTA increases. Vasanth Kumar \& Bagavanalu (2003), reported that, adsorption of dyes on Bioorganic waste shows the saturation point at 60 minutes and the rate kinetics was pseudo first order. Vasanthy (2003) et al., stated that, mixture of adsorbents (Fly ash and activated carbon) removed about 90-100 \% of Chromium at pH 2. Prabhakar \& Palanivel (2003), reported orange TGU, removal depends on initial concentration of the dye and pH condition. Subanandam \& Muttu Velagtydham (2003), stated that, adsorption of Methylene blue on lignite \& fly ash increases with increase in adsorbent dosage, decreases in initial concentration, Shrihari and Raghavendra Kiran (2003), stated that, optimum value of contact time was 15 minutes and obeyed Freundlich isotherms for Iron adsorption. Sanjeev (2003) et al., reported that, adsorption totally depends on dose, $\mathrm{pH}$ and concentration. Adsorption of dyes obeyed both Langmuir and Freundlich isotherms. Anima (2004) et al., stated that, Ni (II) adsorption on rice husk depends on increase in time \& dose. Kannan and Muthuraman (2004), stated that, dyes adsorption on activated charcoal increases with increase in contact time \& dose. 
Singh (2004) et al., reported that, adsorption of copper on maize bran was at optimum $\mathrm{pH} 6.5$, initial copper concentration $40.0 \mathrm{mg} / \mathrm{l}$ and temperature $20^{\circ} \mathrm{C}$. Meena (2004) et al., reported that, Copper adsorption on weathered coal sawdust and carbon aerogel was pH 6 dependent. Kannan and Balamurugan (2004), stated that, copper ions adsorption depends on dose of adsorbent and contact time. Jambulingam (2005) et al., stated that, chromium ion adsorption depends on the initial concentration of metal ion, $\mathrm{pH}$ and agitation time. Srinivasan and Ramadevi (2006), stated that, lead adsorption on Tamarind nut carbon depends on adsorption dosage at an optimum $\mathrm{pH}$ of 5.0. Prabavathi Nagarajan and Priscilla Prabhavathi (2005), stated that, lead adsorption at $\mathrm{pH} 3$, particle size $75 \mu \mathrm{m}$ and contact time 120 min was favourable for adsorption. Kannan and Ramamoorthy (2005) reported that, removal of dyes increased with contact time \& dose. Senthil Nathan and Isaac Solomon Jebamani (2005), stated the Nickel (II) removal using wood of hybrid eucalyptus which depends on optimum dosage of $0.4 \mathrm{~g} / 150 \mathrm{ml}$ and contact time was 10 minutes. Isaac Soloman Jebamani and Saseetharan (2005), reported that Nickel and Lead adsorption on Casuarinas equisettifolia wood was highly dependent on optimum pH 8.2, 20g/L and 15 minutes to remove $91.11 \%$.

Verma and Mishra (2005), reported that, dye removal was $87.5 \%$ to $100 \%$ from $20^{\circ} \mathrm{C}$ to $80^{\circ} \mathrm{C}$, optimum was found to be $60^{\circ} \mathrm{C}$. Kannan and Shakila (2005), reported that sky blue removal obeys Freundlich and Langmuir adsorption isotherms with first order rate kinetics and intraparticle diffusion at the rate determining step. Joshi and Srivastava (2005), stated Pipal bark after chemically carbonized adsorbs 76. 04 \%, at $\mathrm{pH}$ 2. Sharma et al (2005)., reported that decolorising efficiencies of various adsorbents comparatively wood ash removes maximum color of Congored and Chryosophenine-G. Gharde et al (2006)., stated that, Copper adsorption on Tamarindus Indica was $\mathrm{pH}$ dependent at a contact time of 90 minutes. Vasanthy and Sangeetha (2006), reported that, Chromium removal period was $4 \mathrm{hrs}$, with an adsorbent dosage of $1 \mathrm{~g} / 100 \mathrm{ml}$ for 20 to 40 ppm, aqueous Chromium solution at $\mathrm{pH}$ 2, with intra-particle diffusion mechanism. Patil et al (2006), reported that Nickel removal by Babhul bark obeyed Langmuir and Freundlich models of adsorption. Mohammad Ajmal (2006), stated that, maximum adsorption of $85 \%$ was observed at $\mathrm{pH}$ 6, data was correlated by Freundlich and Langmiur isotherm. Chaurasia and Shashikant (2007) stated that Langmiur and Freundlich models were found to have good agreement with experimental data for Methylene blue adsorption on activated saw dust, rice husk ash, boiler bottom ash and wood coal. Syed Shabudeen et al.(2006), stated that, temperature, dose and particle size had influence on adsorption.

Namasivayam and Sumitra (2006), stated that, waste Fe (III)/Cr (III) was used for Brilliant blue and Procion red removal and it was highly effective with agitation. Sheth and Umrigar (2006), stated that, Corncob carbon removed Cadmium through pore diffusion or intraparticle diffusion. Dongo Xinjiao (2006), stated that, Cladosporium species removed Copper at $\mathrm{pH} 5$ and temperature $35^{\circ} \mathrm{C}$ and stirring speed of $100 \mathrm{rpm}$. Dipyendu Banerjee (2007), stated that, fungi and bacteria removes iron at optimal temperature range $30^{\circ} \mathrm{C}, \mathrm{pH} 2.5$ and time 96 to 144 hrs. Mohapatra and Anand (2007), stated that, adsorption of Cd (II) on Lateritic ore obeyed Langmuir and Freundlich isotherms. The short contact time of 30 minutes and good loading capacity of 17.5 $\mathrm{mg} / \mathrm{g}$. Vijaya Kumari and Srinivasan (2007), stated that, Coconut oil cake residue removes mercury with wider $\mathrm{pH}$ range and dose. Lokeshappa et al (2007) stated that, Pseudomonas aeruginosa and Saccharomyces cerevasae found to remove Zinc and Nickel from aqueous solutions at death phase with $72 \mathrm{hr}$ culture. Ahalya et al.(2007), reported that, Cajanus Cajan husk removes Chromium (VI) and Iron (III) and the adsorption was dependent on contact time, $\mathrm{pH}$, initial metal ion concentration and biosorbent dosage. Padmini and Sridhar (2007) stated that Pongamia pinnata bark removes Manganese and Zinc with enhanced adsorbent dose at $\mathrm{pH}$ 7. Umesh (2007), stated that Ni (II) removal from sugarcane bagasse increases with contact time. Madhava Krishnan (2008) et al., reported that, Ricinus communis pericarp carbon removes iron (II), with optimum $\mathrm{pH}$, concentration and dose by obeying Langmuir and Frendlich isotherms. Raja Chandrasekar et al. (2008), stated that, iron adsorption from Borussus bark obeys Langmuir and Freundlich isotherms with positive $\mathrm{R}$ value and both the type of sorption (Chemi and Physisorption). Sneha Narverkar and Varsha (2008), stated that, Chromium sorption by Aspergillus Niger was pH dependent (2.0) Renganathan (2008), stated that, Congo Red dye removal by Tamarindus Indica fruit shell fitted very well with the Freundlich isotherm model. Kannan and Vijayakumar (2008), reported that, Ground nut shell and Coconut shell were correlated with Freundlich and Langmuir isotherms for the removal of Red industrial dye. Chandra sekhar (2008) stated that, removal of Lead by Coconut shell carbon obeyed first order reversible kinetic reaction and sorption isotherm followed Freundlich isotherm. Chakrapani et al (2008)., stated that, Methylene blue by Maize shell carbon depends on pH 6.5, agitation time, dose of the adsorbent. Vasanthy et al (2008)., stated that, Bacterial species adsorb Red RB dye by increasing the dose at acidic pH. Gandhimathi et al (2008), stated that, removal of Copper onto raw rice husk was enhanced at optimum contact time (90 min.) with a regression co-efficient of 0.999. Maji Sanjoy Kumar et al (2008)., stated that, arsenic removal was dependent on the depth of the Laterite soil. Goyal Meenakshi et al.(2008), stated that, Mercury adsorption depends on carbon surface group, which involves attractive electrostatic interactions. Charumathi (2008) et al., stated that, Lead (II) adsorption on pre-treated macro fungus obeyed Freundlich model. Mohammad Ajmal, et al.(2008), stated that, Lead adsorption on teak leaves depends on pH (5) and 
temperature, with endothermic reaction. Sivamani and Prince Immanuel (2008), stated that, Pongamia pinnata removes chromium depending on $\mathrm{pH}$ and contact time. Dash and Satya Sagar (2008), stated that, Zinc adsorption on Shorea Robusta was totally depending on carbon dose, contact time and $\mathrm{pH}$. Madhava Krishnan et al.(2008), stated that, Mercury (II) adsorption on Ricinus Communis carbon was dependent on pH, concentration and dose. Raju and Saseetharan (2008), stated that, Nickel (II) removal depends on optimum dosage, increase in contact time and $\mathrm{pH}$ 4.3. Kannan and Veemaraj (2009), stated that, Zinc removal by Jack fruit seed shows first order with intraparticle diffusion as one of the rate determining steps and depends on $\mathrm{pH}$, contact time and dose.

Meenakshi Sundaram (2009), stated that, Azure-A dye removal from Pomegranate and Tamarind shell obeys Langmuir and Freundlich isotherms. Srinivasan and Hema (2009), stated that, Nickel (II) was adsorbed on Neem oil cake with increase in dose, contact time and pH. Gopalswami et al (2009), reported that, Methylene blue adsorption on Morus plant increased with contact time and achieved equilibrium within a short time. Kalpana et al. (2009), stated that, Terminalia Catappa removes Lead ions with pH 6, contact time 20 minutes, adsorption capacity $28.63 \mathrm{mg} / \mathrm{g}$ and correlation coefficient of 0.9996 . Kale et al.(2009), stated decolorization and degradation of textile azodye Golden Yellow HE2R was done to the extent of $90 \%$ by bacteria. Varsha and Aditi (2009), stated that, white rot fungi Trametes Versicolor was used to remove Reactive black 5 as carbon source (glucose). Vijeta Gupta et al.(2009), stated Cadmium removal from modified Bagasse dust depend on $\mathrm{pH} 6.0$, temperature $25^{\circ} \mathrm{C}$, agitation time $5 \mathrm{hrs}$, sorbent dose $5 \mathrm{~g} / \mathrm{L}$ and $150 \mathrm{rpm}$. Sonawane and Shrivastava (2009), stated that, Methylene blue adsorption on Musa Paradisica obeyed pseudo second order kinetics model. Sonawane and Shrivastava (2008), reported that, Malachite green adsorption on Banana leaves removed $100 \%$ with appropriate dosage of the adsorbent. Pradeep Kumar et al.(2008), stated that, Nigrosine dye removal on petroleum based carbon depends on contact time and dose of adsorbent at $\mathrm{pH}$ 2. Latika Sharan et al.(2008), reported Cyanobacterium adsorption on Cadmium which depends on Contact time. Baskaran and Dhansekar (2008) stated that, removal of dyes by Pleurotus Ostreatus depends on pH 5-8 and it could be achieved by immobilizing the fungus with rice straw. Sudha and Celine (2008), stated Cadmium removal from chitisan coated coconut shell carbon was about $90 \%$ with optimum contact time (120 minutes), agitation speed (60-80 rpm) in acidic condition. Santhalakshmi et al.(2008), stated that, chromium removal by sulphonated black rice husk and Sulphonated white rice husk ash was strongly dependent on $\mathrm{pH}$ 1.0, dose and contact time. Nour El. Din (2008), stated that, Chromium, Copper, Zinc, Cadmium and Lead removal by Nile Rose plant was dependent on $\mathrm{pH}$ and concentration. Suresh et al.(2009), reported that, Bentonite clays remove cationic species. The metal complex cations show better adsorption on to Bentonite. Pravin et al. (2009), stated that, Red soil removes arsenic at $\mathrm{pH} 7.1$ by obeying Langmuir and Freundlich adsorption isotherms. Raju and Saseetharan (2010), reported that, sludge based activated carbon removes Lead (II) at optimum contact time of $20 \mathrm{~min}, \mathrm{pH}$ 5.3, with removal percentage 96. Kannan and Sarojini (2010), reported that, Manganese adsorption on commercial activated carbon depends on increase in contact time, dose of CAC and obey the Freundlich and Langmuir adsorption isotherms. Renugadevi et al.(2010), stated that, pods of wood apple removes Chromium (VI) with spontaneous and exothermic nature of adsorption. Meenakshi Sundaram et al.(2010), stated that, Nile blue A, Safranine and Ethyl violet on commercial activated carbon shows intraparticle adsorption and the process was first order. Nagashanmugam and Srinivasan (2010), reported that, Sulphuric and Zinc treated Gingelly oil cake removes Lead (II) at pH 5.0, dose of $0.1 \mathrm{~g}$ with 99.7 and $72.0 \%$ respectively with pseudosecond order kinetics. The removal was $95.5 \%$ with $\mathrm{pH} 4.0$ and $0.1 \mathrm{~g}$ by commercially activated carbon. Kannan and Veemaraj (2010), reported that, Cadmium and Cadmium- EDTA adsorb on Lemon peel carbon depending on metal ion concentration and $\mathrm{pH}$ dependent with First order intra-particle diffusion. Shrivastava (2010), stated that, Zinc (II) removal by granular activated carbon depends on $\mathrm{pH} 6$ and removal increased with contact time. Renganathan et al.(2010), stated that, Adathoda Vasica removes maximum Chromium at $\mathrm{pH} 2$ with sorbent dosage of $0.02 \mathrm{~g} / 100 \mathrm{ml}$. The equilibrium data fit very well with Freundlich isotherm. Renugadevi et al. (2010), stated that, removal of methylene blue by Cassia Siamea depends on $180 \mathrm{~min}$ of contact time at pH 6 with 400 mg of dose. Sophie Beulah and Muthu Kumaran (2008), stated that, Chromium removal by Syzygium Jambolanum nut carbon was more when it was treated chemically, with the capacity of 4 times higher than CAC. Gupta Vikal and Sharma Manisha (2010), reported that, natural polymer Tamarind Kernal powder removes Chromium (VI) at $10 \mathrm{mg} / \mathrm{L}$, with $65 \%$ removal of Chromium (VI) at $\mathrm{pH} 5.0$ and TKP dose level 5g/L. Yasmin Yamin et al.(2010), reported that, the percentage removal of amido black increased with increase in contact time and adsorbent dose by obeying Langmuir equation. Mallinga et al.(2010), stated that, human hair adsorption of Nickel (II) and Chromium (VI) were maximum at $\mathrm{pH} 6$ and 4 respectively. Hence, the adsorption was totally pH dependent. Gupta Vikal et al. (2010), stated that, Prosopis Cineraria leaf powder removes Copper ions maximum in 240 minutes contact time and at increasing adsorbent amount, $\mathrm{pH}$ 5.5, fitting Langmuir and Pseudo second order equation. Ketcha Mbadcam Joseph and Bougo Tchamande Christelle (2010), stated that, Mercury (II) ions removed by Granular activated carbon and Kaolinite clay highly dependent on dose of adsorbent. The adsorption kinetics was pseudo first order. 
Kannan et al.(2011), stated that, basic dyes onto teak leaf was totally dependent on contact time and dose of adsorbent at acidic $\mathrm{pH}$ by obeying first order kinetics with intraparticle diffusion. Kalaivani et al.(2011), stated that, adsorption of Reactive Red 2 and Acid blue 158 on to Chitin/ Chitisan was influenced by $\mathrm{pH}$ of the medium with spontaneous and endothermic in nature. Dilip Markandey et al. (2011), reported that, 144 hour old Trichoderma Viridae removes metals like Cadmium, Copper, Cobalt, Chromium, Nickel and Zinc from multimetallic aqueous solution at various pH ranges. Anantha Kumar and Krishnammal (2011), stated that, percentage removal of brilliant green on commercial activated charcoal increased with increase in contact time, dose and temperature with monolayer adsorption. Kannan and Veemaraj (2011), reported the Nickel (II) ions removal by Lemon peel and Pomegranate shell carbon, depending on particle size, initial concentration, contact time, dose and pH. Abdo Taher(2011), stated that, Methylene blue on Potato husk was favourable at $\mathrm{pH} 10$, contact time $60 \mathrm{~min}$, at thermodynamic values of $\Delta \mathrm{H}=17.925 \mathrm{KJ} / \mathrm{mole}$ and $\Delta \mathrm{S}=49.426 \mathrm{~J} / \mathrm{mol}$. Raman Kumar $e t$ al.(2011), stated that, Lead and Mercury can be removed by Fungal species which are supported by the presence of functional groups such as $-\mathrm{CH}, \mathrm{C}=\mathrm{O}$ and $-\mathrm{OH}$. Thamilarasu and Karunakaran (2011), stated that, Ni (II) removal by Ricinus Communis seed shell was at optimum contact time of 30 minutes, dosage $50 \mathrm{mg} / 50 \mathrm{ml}$ by Freundlich adsorption. Dilip Markandey et al.(2011), stated that, Chromium (total) adsorb on Rhizopus stonifer depending on $\mathrm{pH}(1-3)$ and contact time with Chemisorption complexation reaction. Renugadevi et al.(2011), stated the malachite green removal using Cassia fistula which depends on $\mathrm{pH} 10$ and 180 minutes as contact time, at initial concentration of $400 \mathrm{mg} / \mathrm{L}$ with $300 \mathrm{mg}$ of the low-cost adsorbent. Theivarasu et al.(2011), stated the reactive orange 16 removal using cocoa shell carbon with monolayer adsorption capacity at $27.02 \mathrm{mg} / \mathrm{g}$ by using Langmuir Model equation with pseudo-second order kinetics equation. Pracilla Prabavathi et al.(2011), stated that, Rice husk and activated alumina were found to be good adsorbents, to remove Rhodamine $\mathrm{B}$ at $\mathrm{pH} 6$ with maximum of $77 \%$ removal at $\mathrm{pH} 3$. Kalpana et al(2011), reported basic Violet 1 dye adsorption on calotropis gigantean biomass with uptake capacity of $138 \mathrm{mg} / \mathrm{g}$ at dose of $0.2 \mathrm{~g} / \mathrm{L}, \mathrm{pH} 2$ and dye concentration of $110 \mathrm{mg} / \mathrm{L}$. Mercy et al. (2011), stated that, Terminalia chebula removes Chromium with optimum metal ion concentration, adsorbent dose, agitation time and pH. Rosaline Vimla et al.(2011), stated the Mercury removal from Castor seed shell was maximum at $\mathrm{pH} 3$ and 4 for CAC by obeying Freundlich isotherms. Renugadevi $e t$ al.(2011), reported Malachite green removal from Caesalpina Pulcherima which depends on Contact time from 10 to $180 \mathrm{~min}$, the adsorption increased with increase in $\mathrm{pH} 2-8$ and $300 \mathrm{mg}$ of the adsorption. Kannan and Kalimuthupandian (2011), stated Methylene blue removal using Rutaceae Vila carbon which depends on contact time and dose of adsorbent at basic pH. Malay Chaudhuri (2011), reported that, Red F-3B and Remazole Blue were removed by coconut coir carbon at $\mathrm{pH} 3.0$, dose $10 \mathrm{~g} / \mathrm{L}$ and increased contact time to remove $96 \%$ for Remazol Blue and $84 \%$ for Remazol Red F-3B, obeying Langmuir and Freundlich adsorption isotherms.

Harminder Kaur et al. (2011), stated that Kigelia Africana was used to remove Copper (II) ions which obeyed Langmuir adsorption isotherm within 30 minutes with Maximum adsorption of $21.74 \mathrm{mg} / \mathrm{g}$. Saritha Yadav et al. (2011), stated that, Congo-red dye removal by Rice husk which depends on initial dye concentration, increase in adsorbate-adsorbent contact period. Anusha and Suneeth Kumar (2011), stated iron adsorption using Limonia acidissima fruit shell which depends on $\mathrm{pH}$ 5.0, optimum dose and concentrations of $1.5 \mathrm{~g}$ and $0.2 \mathrm{mg} / \mathrm{L}$ with contact time of 20 minutes respectively obeying Langmuir isotherm. Bhanupriya Mordhiya et al. (2012), reported the, Methylene blue adsorption on initial dye concentration, contact time, $\mathrm{pH} 7$ obeying Freundlich and Langmuir isotherms with pseudo- second order model.

Based on this, the following adsorbents are used by the researchers for the removal of dyes and metal:

Table-1: Some of the low cost adsorbents used for the removal of dyes:

\begin{tabular}{|l|l|}
\hline Dyes taken for adsorption studies & Low cost adsorbents used by investigators \\
\hline Acid dye & Zinc activated bagasse $^{204}$, Wood and Poots $^{134^{*}}$ \\
\hline Acid violet 17 (acid dye) & Orange peel \\
\hline Acid violet, Congo red and reactive orange & Banana pith ${ }^{113}$ \\
\hline Acid orange-7 \& direct red-31 & Activated carbon $^{111}$ \\
\hline Amido black dye & Calcinated and Uncalcinated Hydrotalcite \\
\hline Azure-A & CAC \& Pomegranate shell and Tamarind shell ${ }^{104}$ \\
\hline Aniline Blue and Acid Violet & Commercially activated carbon $(\mathrm{CAC})^{75}$ \\
\hline Basic violet-1 & Calotropis gigantea \\
\hline Brilliant blue and Procion red & Fe(III)/Cr(III) \\
\hline Brilliant green & Commercial Activated Carbon \\
\hline
\end{tabular}




\begin{tabular}{|c|c|}
\hline Congo red and Chrysophenine-G & $\begin{array}{l}\text { Wood charcoal, Saw dust, Wood ash, Brick } \\
\text { powder, Fly ash, Sugarcane bagasse \& Coir } \\
\text { pith })^{171} \text {, Activated coir pith }{ }^{114} \text {, Tamarindus Indica } \\
\text { fruit shell1 } \\
\text { husk carbon }{ }^{165}\end{array}$ \\
\hline Crystal violet & $\begin{array}{l}\text { Pseudomonas putida }{ }^{26} \text {, Fly ash and commercially } \\
\text { Activated carbon }{ }^{71}, \text { Bacillus subtillis }{ }^{218} \text {, Teak leaf }{ }^{80}\end{array}$ \\
\hline Direct and acid dyes & Soya meal hull ${ }^{14}$ \\
\hline Direct red and Acid brilliant blue & Banana pith ${ }^{117}$ \\
\hline Direct T, Blue R, & Sugarcane bagasse ${ }^{195}$ \\
\hline Dye stuff effluent & Saw dust ${ }^{214}$ \\
\hline Direct blue & Tecomella Undulata (desert plant) $^{83}$ \\
\hline Golden yellow HE2R & Adapted bacteria $^{63}$ \\
\hline Malachite green & 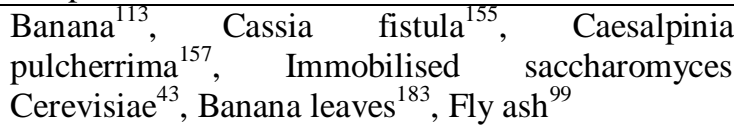 \\
\hline Methyl violet & Pseudomonas mendocina ${ }^{166}$ \\
\hline Methylene blue (Basic dye) & 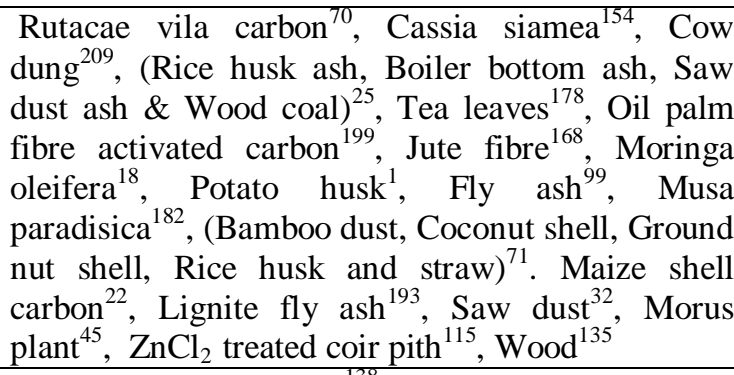 \\
\hline Nigrosine dye & Petroleum based carbon ${ }^{138}$ \\
\hline Nile blue A, Safranine and Ethyl violet & Commercially activated carbon ${ }^{103}$ \\
\hline Orange II & $\begin{array}{llcc}\text { White rot fungus } & \text { (coriolus } & \text { versicolor) } \\
\text { Tecomella Undulata (desert plant) } & & \\
\text { Teco }^{23} & \end{array}$ \\
\hline Orange TGU & Palmnut shell and Fly ash ${ }^{137}$ \\
\hline Procion orangeM2R & Pseudomonas species S5 and Aspergillus flavus ${ }^{170}$ \\
\hline $\begin{array}{l}\text { Procion red and Procion orange, Rhodamine B, } \\
\text { Direct red12B, Congo red }\end{array}$ & $\mathrm{Zn} \mathrm{Cl}_{2}$ treated coir pith ${ }^{115}$ \\
\hline $\begin{array}{l}\text { Reactive dye, Remazole } \\
\text { Remazole blue. }\end{array}$ & $\begin{array}{l}\text { Cashew nut hull carbon }{ }^{212} \text {, Coconut coir activated } \\
\text { carbon }^{99} \text {. }\end{array}$ \\
\hline Reactive orange and Basic Nile blue & Kopak hull activated carbon ${ }^{198}$ \\
\hline Reactive orange-16 & Cocoa shell 203 \\
\hline Reactive red H8B and Direct green & Prosopis cineraria $^{163}$ \\
\hline Reactive red 2 and acid blue & Chitin/ chitisan ${ }^{62}$ \\
\hline Red RB (reactive dye) & $\begin{array}{lllll}\begin{array}{l}\text { Enterobacter } \\
\text { Bacillus }^{211}\end{array} & \text { species, Escherichia } & \text { coli } & \text { and } \\
\end{array}$ \\
\hline Reactive remzole red F-3B \& Remzole blue & Coconut coir activated carbon ${ }^{115}$ \\
\hline Rhodamine-B and Congo red & Orange peel ${ }^{116}$ \\
\hline Rhodomine B and Reactive black 5 & $\begin{array}{l}\text { Rice husk and Activated alumina }{ }^{141} \text {, Fly ash \& } \\
\text { commercially activated carbon }{ }^{100}, \text { Trametes } \\
\text { versicolor (white rot fungi) }{ }^{208}, \text { Teak leaf }\end{array}$ \\
\hline Red industrial dye & Ground nut shell \& Coconut shell carbon $^{78}$ \\
\hline Selective textile dye effluent & Pleurotus ostreatus ${ }^{17}$ \\
\hline Sky blue & Amla and coconut shell ${ }^{79}$ \\
\hline Victoria blue & Fly ash ${ }^{85}$ \\
\hline $\begin{array}{l}\text { Xylenol Orange \& Bromocresol purple, Acid } \\
\text { orange-7 \& Direct red-31 }\end{array}$ & Activated charcoal (Carbon) $^{72}$ \\
\hline
\end{tabular}

* Number in superscript indicates the reference number in the references.

Some of the low cost adsorbents used for the removal of metals: 


\begin{tabular}{|c|c|}
\hline Metals & Adsorbents used \\
\hline Arsenic & $\begin{array}{l}\text { Laterite } \text { soil }^{97} \text {, Thiolated coconut fibre }{ }^{54} \text {, Zirconium loaded activated charcoal }{ }^{131} \text {, Red } \\
\text { soil }^{140}\end{array}$ \\
\hline Chromium & 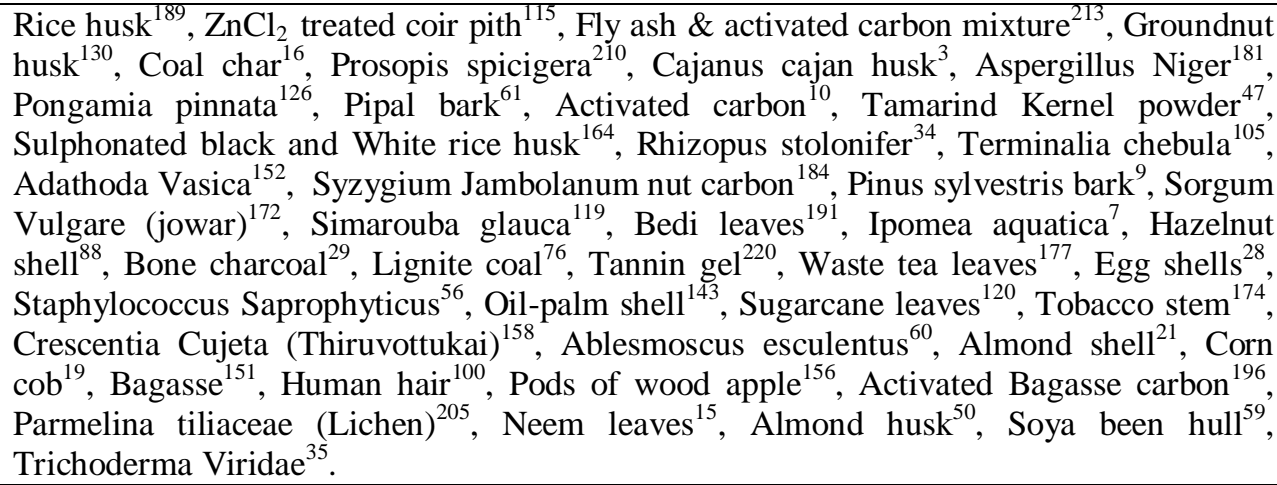 \\
\hline Cadmium & 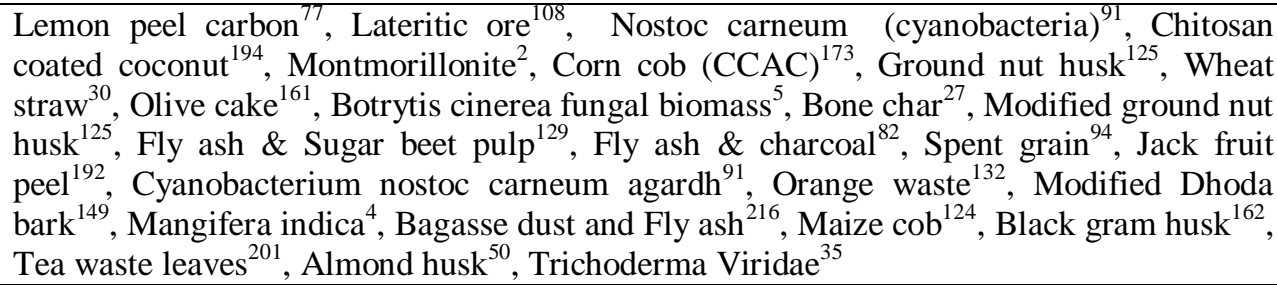 \\
\hline Cobalt & Maize $\operatorname{cob}^{53}$, Trichoderma Viridae ${ }^{35}$ \\
\hline Copper & 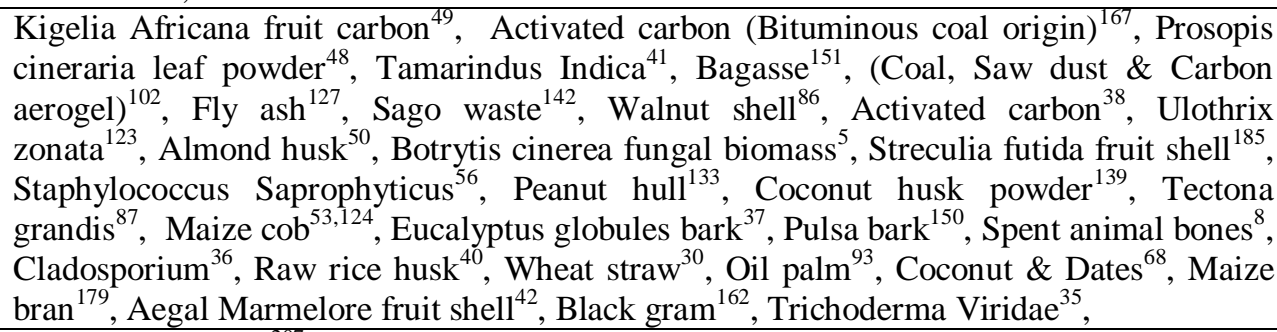 \\
\hline Gold & Activated Bagasse ${ }^{207}$ \\
\hline Iron & $\begin{array}{l}\text { Limonia acidissima (Wood apple })^{13} \text {, Thiobacillus ferroxidans and Bacteria }{ }^{33} \text {, Cajanus } \\
\text { cajan husk }^{3} \text {, Ricinus communis pericarp carbon }{ }^{96} \text {, Borassus bark }{ }^{144} \text {, activated carbon }{ }^{38} \text {, } \\
\text { Rhizopus Arrhizus }^{6} \text {, Maize } \operatorname{cob}^{53} \text {, Laterite }\end{array}$ \\
\hline Lead & 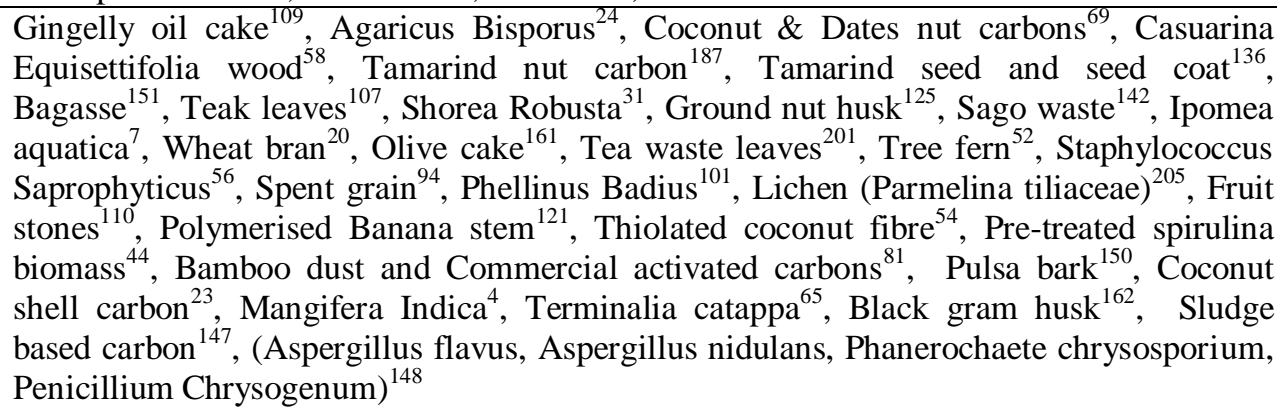 \\
\hline Mercury & $\begin{array}{l}\text { Castor seed shell }{ }^{160} \text {, Activated carbons } \mathrm{s}^{46}, \mathrm{ZnCl}_{2} \text { treated coir pith }{ }^{115} \text {, Ricinus Communis } \\
\text { Pericarp }{ }^{95} \text {, Thionated coconut fibre }{ }^{54} \text {, Palm shell powder }{ }^{84} \text {, Zirconium loaded activated } \\
\text { charcoal }^{131} \text {, Kaolinite clay and Granular activated carbon }{ }^{84} \text {, Peanut hull }{ }^{118} \text {, Coconut oil } \\
\text { cake residue }{ }^{215} \text {, Terminalia catappa }{ }^{57} \text {, (Aspergillus flavus, Aspergillus nidulans, } \\
\text { Phanerochaete chrysosporium, Penicillium Chrysogenum) }{ }^{148} \text {. }\end{array}$ \\
\hline Molybdenum & $\mathrm{ZnCl}_{2}$ treated coir pith ${ }^{115}$ \\
\hline Manganese & Pongamia pinnata bark ${ }^{126}$, Commercially activated carbon $^{74}$ \\
\hline Nickel & $\begin{array}{l}\text { Sludge based activated carbon }{ }^{146} \text {, Casuarina Equisettifolia wood }{ }^{58} \text {, Activated alumina }{ }^{159} \text {, } \\
\text { Ground nut shell }{ }^{106} \text {, Babul Bark \& PAC }{ }^{128} \text {, Sugar cane bagasse }{ }^{206} \text {, Pseudomonas } \\
\text { aeruginosa and Saccharomycces cerevisiae }{ }^{92} \text {, Activated carbon }{ }^{38} \text {, Coconut residues }{ }^{188} \text {, } \\
\text { Neem oil cake }{ }^{186} \text {, Parthenium histerophorus }{ }^{90} \text {, sugarcane fibre }{ }^{55} \text {, Eucalyptus globules } \\
\text { bark }^{37} \text {, Aegal Marmelose fruit shell }{ }^{42} \text {, Pulsa bark }{ }^{150} \text {, Rice husk }{ }^{12} \text {, Bentonite } \text { clay }^{197} \text {, } \\
\text { Mangifera Indica }^{4} \text {, Human hair }{ }^{100} \text {, Lemon peel carbon and Pomegranate shell }{ }^{67} \text {, Spent } \\
\text { animal bone }{ }^{8} \text {, Hybrid Eucalyptus }{ }^{169} \text {, Almond husk }{ }^{51} \text {, Ricinus Communis seed shell }\end{array}$ \\
\hline
\end{tabular}




\begin{tabular}{|c|c|}
\hline & Bagasse $^{151}$, Trichoderma Viridae ${ }^{35}$ \\
\hline Selenium & Zirconium loaded activated charcoal ${ }^{131}, \mathrm{ZnCl}_{2}$ treated coir pith ${ }^{115}$ \\
\hline Uranium & Pinus radiate 39 \\
\hline Vanadium & $\mathrm{ZnCl}_{2}$ treated coir pith ${ }^{115}$ \\
\hline Zinc & $\begin{array}{l}\text { Tea leaves carbon }{ }^{201} \text {, Sludge based activated carbon }{ }^{147} \text {, Bituminous coal origin }{ }^{167} \text {, } \\
\text { Mangifera indica seed shell }{ }^{4} \text {, Pseudomonas aeruginosa and Saccharomyces cerevisiae }{ }^{92} \text {, } \\
\text { Pongamia pinnata bark }{ }^{126} \text {, Jack fruit seed \& Commercial activated carbons }{ }^{66} \text {, Fly ash and } \\
\text { Sugar beet pulp }{ }^{129} \text {, Pulsa bark }{ }^{150} \text {, Shorea Robusta (leaves) }{ }^{31}, \text { Fly ash }^{190}, \text { Sugarcane fibre }^{55} \text {, } \\
\text { Trichoderma Viridae }{ }^{35} \text {. }\end{array}$ \\
\hline
\end{tabular}

\section{* Number in superscript indicates the reference number in the references.}

\section{Conclusion:}

The use of commercially activated carbon can be replaced by the inexpensive and effective low cost adsorbents. There is need for more studies to understand better process of low-cost adsorbents and to demonstrate the technology effectively. Various low cost adsorbents show a high degree of removal efficiency for heavy metals and dyes. If low -cost adsorbents perform well in removing heavy metal complexes and dyes at low cost, they can be adopted and used widely in industries, not only to minimize cost but also to improve profit. In addition to this, the living organisms and the surrounding environment will also be benefited from the decrease or elimination of the potential toxicity due to the heavy metals and dyes

\section{Reference:}

[1]. Abdo Taher, Maqdoom Farooqui and Mazahar Farooqui, (2011). Study of Adsorption Equilibrium of Methylene blue with low cost adsorbent, Indian Journal of Environmental protection, , 31(4): 22-326.

[2]. Abraham, B.T. and Anirudhan, T.S., (1998). Influence of humic acid and pH on Cadmium (II) Adsorption on montmorillonite, Indian Journal of Environmental protection, 19(5): 363-366.

[3]. Ahalya, N., Kanamadi, R.D., and Ramachandra, T.V, (2007). Chromium (VI) and Iron (III) removal using cajanus cajan husk, $J$. Environ. Biol., 28(4): 765-769.

[4]. Ajmal, Ali mohamad, Rehana Yousuf and Anus Ahmad, (1998). Adsorption behaviour of Cadmium, Zinc, Nickel and Lead from aqueous solutions by Mangifera Indica seed shell, Indian Journal of Environmental Health, , 40 (1): 1-5.

[5]. Akar, T. and Tunali, S., (2005). Biosorption performance of Botrytis Cinerea fungal by products for removal of $\mathrm{Cd}(\mathrm{II})$ and $\mathrm{Cu}$ (II) ions from aqueous solution. Minerals Eng, 18: 1099-1109.

[6]. Aksu, Z., (1999). Biosorption of iron (III)-cyanide complex anions to Rhizopus Arrhizus-Application and adsorption isotherms. Process. Bio chem., 34: 483-491.

[7]. Alam, A. and Chatterji, A.K, (1994). Ipomea aquatica as a possible biomonitor of aquatic lead and chromium pollution, Recent researches in Ecology, Environment and Pollution, 9: 271-277.

[8]. Al-Asheh, S., Banat, F., Mohai, F., (1996). Sorption of Cu and Ni by spent animal bones. Chemosphere, 39: 2087-2096.

[9]. Alves, M.M, Gonzalez Beca, C.G. Guedes, De Carvealho, R, Castanheria, J.M, Sol Percira, M.C and Vason ceslos, L.A.T, (1993). Chromium removal in tannery waste waters polishing stage by pinus sylvestris bark, J, Water Resources, 22: 1333-1338.

[10]. Amal Raj, S and Srinivasa Raghavan, R, (2002). Removal of chromium on synthetic effluent by adsorption on activated carbon, Indian J. Environmental Protection, , 22(1): 69-72.

[11]. Anantha Kumar, K., Krishnammal, A, (2011). Thermodynamics and Isotherm modelling of Adsorption of Brilliant green on commercial activated charcoal, Indian Journal of Environmental protection, 31(4): 315-321

[12]. Anima, S, Dadhich, Shaik khasim Beebi and Kavitha G.V, (2004). Adsorption of Ni (II) using agro waste -Rice husk, Journal of Environ science \& Engg, 46(3): 179-185.

[13]. Anusha, G and Suneeth Kumar, S.M, (2011). Adsorption of Iron from aqueous solution using Limonia acidissima fruit shell activated carbon as an adsorbent, J. Nat. Env. And Poll. Tech, 10(4): 637-638.

[14]. Asami, M, (2011). Equilibrium and Kinetic studies for the adsorption of direct and acid dyes from aqueous solutions by soya meal hull. J. Hazardous Materials, B(135): 171-179.

[15]. Babu, B.V and Gupta, S. (2008). Adsorption of Cr (VI) using activated Neem leaves: kinetics studies, Adsorption, 14(1): 85-92.

[16]. Baisakh, P.C and Patnaik, S.N, (2002). Removal of hexavalent Chromium from Aqueous solutions by adsorption on coal char. Indian J. Environ health, , 4(3): 189-196.

[17]. Baskaran, $\mathrm{V}$ and Dhansekhar, R, (2008). Decolourization Kinetics of selective textile dyeing effluents using pleurotus ostreatus, $J$. The Ecoscan , 2(1): 29-34.

[18]. Bhanupriya Mordhiya, Kailash Daga, Suresh Chandra and Sonia aggarwal, (2012). Adsorptive treatments of Methylene blue dye from aqueous solution using Moringa oleifera as an adsorbent, J. Nat. Env. Poll. Tech. 11(1): 113-116.

[19]. Bosinco, S, Roussy, J, Guibal, E and Lecloirec, P, (1996). Interaction Mechanisms between hexavalent Chromium and Corn cob, Environmental Technology, 17: 55-62.

[20]. Bulut, Y and Baysal, Z, (2006). Removal of $\mathrm{Pb}$ (II) from wastewater using Wheat bran. J. Environ. Manag., 78: 107-113.

[21]. Candela, M.P, Martinez, J.M. and Macia, R.T, (1995). Chromium (VI) removal with almond shell, Water Resources, 29: 21742180 .

[22]. Ch. Chakrapani, Ravi. M, Somasekhar Rao K, Suresh Babu. Ch, Venkateswara Rao.V and Srinivasa Rao V, (2008). Removal of Methylene blue by Maize shell carbon, Indian Journal of Environmental protection, 28(6): 547-553.

[23]. Chandra Shekar, M, (2008). Removal of Lead from aqueous effluents by adsorption on coconut shell carbon, J. Journal of Environ Science \& Engg., 50(2): 137-140.

[24]. Charumathi, D, Vimala, R and Nilanjana Das, (2008). Langmuir and Freundlich isotherms for describing lead(II) adsorption on pretreated macrofungus (Agaricus Bisporus), J. Nature. Environ. Pollu. Tech., 7(2): 307-310. 
[25]. Chaurasia, S and Shashikant, (2007). Removal of Basic dye from aqueous solution using Natural adsorbents: Equilibrium and diffusion studies, Indian J. Environmental protection, 27(6): 538-544.

[26]. Chen, C.C, Liao, H.J and Cheng, C.V. (2007). Biodegradation of Crystal violet by pseudomonas putida. Biotechnol. Lett. 29: 391396.

[27]. Cheung, C.W, Porter, J.F and Mckay, G, (2001). Sorption kinetic analysis for the removal of cadmium ions from effluents using bone char, J. of water research, . 35(3): 605-612.

[28]. Chojnacka, K. (2005). Biosorption of Cr (III) ions by Egg shells. J. Hazardous Materials, B121: 167-173.

[29]. Dahbi, S, Azzi, M, Saib, N, Guardia, D.M, Fause, R and Durand, R, (2002). Removal of trivatent chromium from tannery waste water using bone charcoal, Analytical Bioanalylitical Chem. 374: 540-546.

[30]. Dang, V.B.H, (2009). Adsorption of Cadmium (II) and Copper (II) ions by wheat straw, Bioresources Tech.,. 100 (1): $211-219$.

[31]. Dash, S. Nand Satya Sagar, P, (2008). Adsorption of Zn metal from paper mills waste water by activated carbon prepared from Shorea Robusta leaf litter, J. Nat. Environ. Pollu. Techno,. 7(1): 117-122.

[32]. De. D.S and Basu, J.K, (1999). Adsorption of Methylene blue on to a low cost adsorbent developed from saw dust, Indian Journal of Environmental protection, 19(6): 416-421.

[33]. Dibyendu Banerjee, (2007). Biosorption of Iron by thiobacillus ferroxidans and Bacteria -isolated from steel plant waste, J. Poll. Res..26(1): 171-175.

[34]. Dilip Markandey, Salar R.K, Markanddey, N and Trivedi, R.C, (2011). Suitability of Rhizopus stolonifer for removal and recovery of $\mathrm{Cr}(\mathrm{T})$ from dilute tannery effluent, Indian Journal of Environmental protection, 31(7): 560-568.

[35]. Dilip Markandey, Salar, R.K, Trivedi, R.C, Markandey, N, Maiti, S.K, Anil Prakash, B.K, Choudhury, Jagdish and Gurdeep Singh, (2011). Suitability of Trichoderma Viridae for Removal and Recovery of $\mathrm{Cd}, \mathrm{Cu}, \mathrm{Co}, \mathrm{Cr}(\mathrm{T}), \mathrm{Ni}$ and $\mathrm{Zn}$, Indian Journal of Environmental protection,. 31(4): 301-314.

[36]. Dong xinjiao, (2006), Biosorption of copper from aqueous solutions by pretreated cladosporium species, Journal of Environmental Biology, 27(4): 639-643.

[37]. Doulatani, D.K, Rode, D.M, Haware, D.J and Patil, P.V. (1999). Use of Eucalyptus globules bark substrate for the removal of Cu (II) and Ni (II) from solution using Aegal Marmelose fruit shell substrate. Asian J. of chemistry, 3(2): 33-36.

[38]. Edwin Vasu, A, (2008). Adsorption of Ni (II), Cu (II) and Fe (III) from aqueous solutions using activated carbon, E-Journal of chemistry, 5(1): 1-9.

[39]. Freer, J, Baeza Maturana, H, Palma, G and Duran, N, (1989). Removal and recovery of Uranium by modified pinus radiate Don Bark. J. of chemical technology and Biotechnology. 46: 41-48.

[40]. Gandhimathi, R, Ramesh, S.T and Arun Praveeth, (2008). Adsorption removal of copper from aqueous solution on to Raw-Rice husk: Kinetics and isotherms. J. Nat. Environ. Pollu. Technology, 7(4): 763-768.

[41]. Gharde, B.D, Gholse, S.B and Patil, P.V, (2006). Removal of Copper (II) from aqueous solution using tamarindus indica fruit shell substrate. J. Poll. Res., 25(2): 449-450.

[42]. Gharde, B.D, Gholse, S.B and Patil, P.V, (2005). Removal of Cu (II) and Ni (II) from solution using Aegal Marmelose fruit shell substrate. Asian J. of Chemistry, 17(1): 191-194.

[43]. Godbole, P.T and Sawant, A.D. (2006). Removal of Malachite green from aqueous solution using immobilized saccharomyces cerevisiae. J. Sci. Ind. Res., 65: 440-442.

[44]. Gong, R., Ding, Y.D., Liu, H, Chen, Q and Liu, Z, (2005). Lead adsorption by intact and pre-treated spirulina maxima biomass, Chemosphere, 58: 125-130.

[45]. Gopalaswami, P.M, Ponnusamy, S, Sivakumar, N, and Ilamparithi, A, (2009). Methylene blue adsorption onto low cost powdered activated carbon from agricultural waste Morus Plant, J. Nat. Env. Poll. Tech.,. 9(2): 317-322.

[46]. Goyal Meenakshi and Amutha, R, (2008). Adsorption of Hg (II) ions from water by Activated carbons. Res. J. chem. Environ., 12 (1): 76-83.

[47]. Gupta Vikal and Sharma Manisha,(2010). Adsorption analysis of chromium (VI) by Natural polymer Tamarind Kernel powder (TKP) in aqueous medium, Research Journal of Chemistry and Environment, . 14(1): 41-45.

[48]. Gupta Vikal, Kulshreshtha Ruchi and Lalmagan, (2010). Bioremediation of Copper (II) from aqueous solution using prosopis cineraria leaf powder, Res. J. Chem. Environ. 14(3): 51-56.

[49]. Harmindu Kaur, Radha Shyam and Amutha, R, (2011). Kigelia Africana fruit carbon as a low cost adsorbent of removal of copper (II) ions from aqueous solution, J. Nat. Env, and Poll. Tech,. 10(3): 419-422.

[50]. Hasar, H and Luci, Y,(2000). Removal of Chromium (VI), Cd (II), and Cu (II) by activated carbon prepared from almond husk, Environ. Technol. 21:1337-1342.

[51]. Hasar, H, (2003). Adsorption of nickel (II) from aqueous solution onto activated carbon prepared from almond husk J. Hazard Materials, 9: 49-54.

[52]. Ho, Y.S, (2004). Sorption of Lead ions from aqueous solution using tree fern as a sorbent, Hydrometallurgy,. 73: 55-61.

[53]. Igwe, J.C and Abia, A.A, (2007). Adsorption kinetics and intraparticulate diffusivities for Bioremediation of Co (II), Fe (II), Cu (II) ions from waste water using modified and unmodified Maize Cob, J. Phy. Sci., 2(5): 119-127.

[54]. Igwe, J.C. Abia, A.A and Ibeh, C.A, (2008). Adsorption kinetics and Intraparticulate diffusivities of $\mathrm{Hg}$, As, and Pb ions on unmodified and Thiolated coconut fibre, Int. J.Environ. Sci. Tech., 33: 617-623.

[55]. Ikhuoria, E.U and O.C Onojie, (2007). Binding of Nickel and Zinc ions with activated carbon prepared from Sugarcane fibre (Saccharum Officinarum L). Bulletin of the chemical society of Ethiopia, 21(1): 151-156.

[56]. Ilhan, S, Naubakhsh, M.N., Kilicarslan, S and Ozdag, H, (2004). Removal of Chromium, Lead and Copper ions from industrial waste water by staphylococcus saprophyticus. Turk. Electronic J. Biotechnol., 2: 50-57.

[57]. Inbaraj, B.S and Sulochana, N, (2006). Mercury adsorption on a carbon sorbent derived from fruit shell of Terminalia catappa. J. Hazardous Materials, 133: 283-290.

[58]. Isaac Solomon Jebamani, M and Saseetharan, M.K, (2005). Adsorption batch studies on Ni (II) and Pb (II) removal using bark of Casuaria Equisettifollia wood based activated carbon. J. Nat. Environ. Pollu. Techn., 4(3): 345-351.

[59]. Jambulingam, M, Renugadevi, N, Karthikeyan, S, Kiruthika, J and Patabhi, S, (2005). Adsorption of chromium (VI) from aqueous solution using a low cost activated carbon. Indian J. Env. Protectc, 25 (5), 458-463.

[60]. Jasuja, K, Parwana, H.K and Rao, A.L.J, (1997). Removal of Cr (VI) from waste water by Ablesmoschus esculents. Indian J. Env. Health,. 39(2): 103-108.

[61]. Joshi, M, and Srivastava, R.K, (2005). Chromium (VI) removal from waste water by using carbonized pipal bark adsorbent. Indian J. Environmental Protection, 25(1): 57-60.

[62]. Kalaivani, G, Sowmya, A and Meenakshi, S, (2011). Removal of reactive Red 2 and acid blue 158 onto chitin/ chitisan, Indian Journal of Environmental protection,. 31(4): 292-300. 
[63]. Kale, R.V, Sable, M.M and Thorat, P.R, (2009). Decolorization and degradation of textile azo dye golden yellow HE2R by adapted bacteria, J. Nat. Env. Poll. Tech., 9(2): 351-354.

[64]. Kalpana, J, Saravanan, P, Nagendra Gandhi, N and Ranganathan, S, (2011). Equilibrium modeling on Biosorption of Basic violet 1 dye using calotropis gigantean Biomass, Indian Journal of Environmental protection, 31 (10): 825-832.

[65]. Kalpana, P, Rakesh, N and Nageswara Rao, L, (2009). Biosorption of lead ions from aqueous solution by Terminalia catappa L.: Equilibrium and Kinetic studies, J. Nat. Env. Poll. Tech., 9(2): 335-343.

[66]. Kannan, N and Veemaraj, T, (2009). Kinetics of Adsorption for the Removal of Zinc(II) ions from Aqueous solution using indigenously prepared Jack fruit seed and Commercial activated carbons, Indian Journal of Environmental protection, 30(5): 366373.

[67]. Kannan, and Veemaraj, (2011). Detoxification of Nickel (II) ions by adsorption onto carbons prepared from agricultural materials A comparative study, Indian Journal of Environmental protection, 31(4): 338-344.

[68]. Kannan, N and Balamuragan, J, (2004). Removal of Copper ions by adsorption onto coconut shell and dates nut carbons-A comparative study, Indian Journal of Environmental protection, 24 (5): 371-378.

[69]. Kannan, N and Balamuragan, J, (2005). Removal of lead ions by adsorption onto coconut shell and dates nut carbons-A comparative study, Indian Journal of Environmental protection, 25 (9): 816-823.

[70]. Kannan, N and Kalimuthupandian, S, (2011). Studies on the removal of Methylene blue (MB) by adsorption on Rutaceae Vila carbon, Indian Journal of Environmental protection, 31(10): 855-859.

[71]. Kannan, N and Meenakshi Sundaram, M, (2002). Kinetics of Adsorption of Dyes on activated carbon: A comparative study, Indian Journal of Environmental protection, 22(1): 9-16.

[72]. Kannan, N and Muthuraman, A, (2004) Studies on the removal of xylenol orange and Bromocresol purple by adsorption on activated charcoal, Indian Journal of Environmental protection,. 24(11): 849-855.

[73]. Kannan, N and Ramamoorthy, K, (2005). Studied on the removal of dyes by adsorption on orange peel, Indian journal of Environment protection, 25(5): 410-416.

[74]. Kannan, N and Sarojini, P, (2010). Studies on the Removal of Manganese (II) ions by adsorption on commercial activated carbon, Indian Journal of Environmental protection, . 30(5): 404-408.

[75]. Kannan, N and Thamaraichelvi, (2005). Studies on the removal of Aniline Blue and Acid Violet by commercial activated carbon, Indian J. of Environmental Protection, 25(1): 1-7.

[76]. Kannan, N and Vanangamudi, A., (1991). A Study on removal of Chromium (VI) by adsorption on lignite coal, Indian J. Env. Prot., 11(4): 241-245.

[77]. Kannan, N and Veemaraj, T, (2010). Dynamics and equilibrium studies for the removal of Cadmium and Cadmium-EDTA onto Lemon peel carbon, Indian Journal of Environmental protection, 30(1): 26-33.

[78]. Kannan, N and Vijay Kumar, A, 2008. Comparative study on the removal of red industrial dye using Ground nut shell and coconut shell carbon, Indian Journal of Environmental protection, 28 (11), 1034-1040..3

[79]. Kannan, N, Shakila, O.P, (2005). Studies on the removal of sky blue by adsorption on Amla and coconut shell carbons, Indian Journal of Environmental protection, 25(5): 437-443.

[80]. Kannan, N, Vijay Kumar, A and Subramanian, P, (2011). Adsorption of Basic dyes onto activated carbon prepared from teak leaf, Indian Journal of Environmental protection, 31(7): 552-559.

[81]. Kannan, N. and Veemaraj, T. 2009. Removal of lead (II) ions by adsorption onto bambodust and commercial activated carbons -A comparative study Electronic J. Chemistry, 6(2), 247-256.

[82]. Kannan, N and Umamathi, T, (2003). Studied on the EDTA assisted removal of cadmium (II) ions by adsorption onto mixed adsorbents, Indian J. Environmental protection, 23 (1): 41-46.

[83]. Katyal, S.K and Daga, K., (2003). Removal of dyes by an adsorbent revived from Tecomella undulate in Western Rajasthan, Indian J. Environ. protect. 23(1): 37-40.

[84]. Ketcha Mbadcam Joseph and Baugo Tchamande christelle, (2010), Removal of Mercury (II) ions from aqueous solutions using granular activated carbon (GAC) and Kaolinite clay from Mayouom in Cameroon: Kinetics and equilibrium studies, Res. J. Chem. Environ. 14(3): 60-65.

[85]. Khare, S.K, Pandey, K.K, Srivastva, R.M and Singh, V.N, (1987). Removal of Victoria blue from aqueous solution by fly ash. J, Chem. Tech. Biotech, 38: 99-104.

[86]. Kim, J.W, (2001). Production of granular activated carbon from waste walnut shell and its adsorption characteristics for $\mathrm{Cu}^{2+}$ ion. J. Hazardous Materials, 85: 301-315.

[87]. King, P, Srinivas, P, Prasanna Kumar, Y and Prasad, V.S.R.K. (2006). Sorption of copper (II) ion from aqueous solution by Tectona grandis (teak leaves powder). J. Hazardous Materials, 136 (3): 560-566.

[88]. Kobya, M, (2004), Adsorption kinetics and equilibrium studies of Cr (VI) by hazelnut shell activated carbon. Adsorption Scince technology, 22: 51-64.

[89]. Kushwaha shilpi, Sodaye Suparna and Polmaja, P., (2008). Equilibrium, Kinetics and Thermodynamics studies for adsorption of $\mathrm{Hg}$ (II) on palm shell powder, PWASET,. 33: 617-623.

[90]. Lata, H, Garg, V.K. and Gupta, R.K. (2007).Sequestration of nickel from aqueous solution on to activated carbon prepared from parthenium hsterophorus , J. Hazardous Materials, 157(2-3): 503-509.

[91]. Latika Sharan, Bharati Raipat and Sinha, M.P, (2008). Biosorption of cadmium from aqueous medium by Cyanobacterium Nostoc Carneum Agardh, J. The Ecoscan, 2(1): 125-127.

[92]. Lokeshappa, B, Shivayogimath, C.B and Gupta, K.G, (2007). Biosorption studies of heavy metals (Zn \& Ni) by Pseudomonas Aeruginosa and saccharomyces cerevisiae, Indian .J. Environmental protection, 27(12): 1098-1102.

[93]. Low, K.S, Lee, C.K and Lee, K.P. (2002). Sorption of Copper by dye treated oil palm fibres. Waste management, 22 (5): $471-480$.

[94]. Low, K.S, Lee, C.K and Liew, S.C. 2000, Sorption of Cd (II) and Pb (II) from aqueous solutions by spent grain. Process Biochem. 36: 59-64.

[95]. Madhavakrishnan, S, Manickavasagam, K, Mohanraj, R, Kadirvelu, K and Pattabhi, S, (2008). Removal of Mercury (II) from aqueous solution by adsorption onto Ricinus Communis pericarp activated carbon, Indian. J. Environmental Protection,. 28(11): 967-972.

[96]. Madhvakrishnan, S. Manickavaragam, .K, Sameena, Y, Selvam, K, Kairvelu, K. and Pattabhi, S, (2008). Adsorption of Iron (II) from Aqueous solution using Ricinus communis pericarp carbon as an Adsorbent, 7(3): 391-396.

[97]. Maji sanjoy Kumar, Pal Anjali and Pal tarasankar, (2008). Arsenic Removal House hold filter for small community. Research Journal of Chemistry and Environment, 12(1): 23-32.

[98]. Malay Chaudhuri, Emad, S. Elmolla and Rashidah Bt. Othman, (2011). Adsorption of reactive dyes Remazol Red F-3B and Remazol blue from aqueous solution by coconut coir activated carbon, J. Nat. Env. And Poll. Tech., 10(2): $193-196$. 
[99]. Mall, I.D and Upadhyay, S.N., (1998). Studies on Treatment of basic dyes bearing waste water by adsorptive treatment using fly ash, Indian Journal of Environment health, 40(2): 177-188.

[100]. Malliga, D, Jeyanthi, G.P and Bhuvaneswari, V. (2010). Adsorption of Nickel (II) and Chromium (VI) from synthetic metal solutions using powdered human hair as adsorbent, J.Ecotoxicology. Environ. Monit, 20(1): 39-50.

[101]. Matheickal, J.T and Yu. Q. (1997). Biosorption of Pb (II) from aqueous solutions by phellinus badius. Miner. Eng., 10 (9): 947957.

[102]. Meena, A.K, Mishra, G.K, Nagar, P.N and Chitra Rajgopal, (2004). Removal of copper (II) from aqueous solution by different adsorbents, Indian J. Environmental Protection, 24(5): 361-370.

[103]. Meenakshi Sundaram, M, Kannan, N and Rejinis, J, (2010). Adsorption Kinetics of Nile Blue A, safranine and ethyl violet on commercial activated carbon -A comparative study, Indian Journal of Environmental protection, 30(1): 1-9.

[104]. Meenakshi Sundaram, M, Kannan, N and Rejinis, J, (2009). Removal of Azure A from aqueous solution by CAC and New activated carbon from pomegranate shell and Tamarind shell, Indian Journal of Environmental protection, 29(6): 505-513.

[105]. Mercy, C.I, Saranya, K.P and Kala, K, (2011). Adsorption of chromium from aqueous solutions by Terminalia chebula-A kinetic approach, Indian Journal of Environmental protection, 31(10): 833-841.

[106]. Mohammad Ajmal, R.A.K. Rao, Jameel Ahmad and Rais Ahmad. (2006). The use of ground nut shell (Arachis hypogea) for the adsorption of Ni (II) from the aqueous System, Journal of Environ. Science \& Engg., 48 (3): 221-224.

[107]. Mohammad Ajmal, Rifaqatak, Rao, Jameel Ahmad shanana anwar and Rais Ahmad, Adsorption studies on teak leaves (Tectona grandis): (2008). Removal of lead Ions from waste water, Journal of Environ. Science \& Engg, 50(1): 7-10.

[108]. Mohapatra, M and Anand, S, (2007). Cd (II) adsorption on high iron containing lateritic ore of Orissa, Indian J. Environment Protection, 27(6): 509-515.

[109]. Nagashanmugam, K.B and Srinivasan, K, (2010). Removal of Lead (II) form aqueous solution by carbons derived from chemically modified Gingelly oil cake, Indian Journal of Environmental protection, 30(1): 10-25.

[110]. Nageeb, Mohammad pashed, (2005). Fruit stones as adsorbents for the removal of lead ion from polluted water, chemistry department, Faculty of Science, 152872, Aswan, Egypt.

[111]. Nageswara, Rao A, Lathsree, S, Sivasankar, B, Sadasivam, V and Rengaraj, K, (2004), Removal of azo dyes from aqueous solutions using activated carbon as an adsorbent. Journal of Environ. Science \& Engg. 46(2): 172-178.

[112]. Namashivayam, C and Sumithra, S, (2006). Adsorption of Anionic dyes on to waste Fe (III)/Cr (III), Journal of Environ Science \& Engg. 48(1): 69-74.

[113]. Namasivayam, C and Kanchana, N, (1992). Waste Banana as adsorbent for colour removal from waste water. Chemosphere, 25: 1691-1705.

[114]. Namasivayam, C and Kavitha, D, (2002). Removal of Congo red from waste water by adsorption on to activated carbon prepared from coir pith an agricultural solid waste, Dyes and pigments, 54: 97-58.

[115]. Namasivayam, C and Sangeetha, D, (2006). Recycling of agricultural solid waste, coir pith, removal of anions, heavy metals, organics and dyes from water by adsorption onto $\mathrm{ZnCl}_{2}$ activated coir pith carbon, Journal of Hazardous materials, . B135: 449456.

[116]. Namasivayam, C, Munisamy, N, Gayathri, K, Rani, M, Ranganathan, K, (1996). Removal of dyes from aqueous solutions by cellulosic waste orange peel. Bioresources Technology, 57: 37-43.

[117]. Namasivayam, C, Prabha, D and Kumatha, M, (1998). Removal of direct red and acid brilliant blue by adsorption onto banana pith. Bioresources. Tech, 64: 77-79.

[118]. Namasivayam, C. and Periasamy, K, (1993). Bicarbonate- treated peanut hull carbon for Mercury (II) removal from aqueous solutions. Water Research, 27: 1663-1668.

[119]. Neelavathi, (2004). Removal of toxic Cr (VI) by the adsorption of activated carbons prepared from Simarouba shells, Journal of Env. Science and Engg. 46(2): 137-142,

[120]. Nigam Arrti and Rama, O.P. (2003). Removal of hexavalent chromium by using (agro based waste material) sugarcane leaves as adsorbent. Asian J. of Microbiology \& Biotechnology, 5(3): 349-352.

[121]. Noeline, B.F, Manohar, D.M and Anirudhan, T.S. (2005). Kinetic and equilibrium modelling of lead (II) sorption from water and waste water by polymerized banana stem in a batch reactor. Separation and Purification technology, 45(2): 131-140.

[122]. Nour El-Din, T. Abdel-Ghani and Ghadir, A. El-1Chaghaby, (2008). The use of low cost and environment friendly materials for the removal of heavy metals from aqueous solutions, J.Current world Environment, 3(1): 31-38.

[123]. Nuhoglu, Y, (2002), The removal of Cu (II) from aqueous solutions by Ulothrix zonata Bioresources, Technology, 85(3): $331-333$.

[124]. Okeiman, F.E and Okunodye, J,N, (1989), Removal of Cadmium and Copper ions from aqueous solution with Maize cob. Biological Waste, 30: 325-330.

[125]. Okiemen, F.E, Okundia, E.V and Ogbeifun, D.E, (1991). Sorption of Cadmium and lead ions on modified ground nut husk (Arachis hypogea) husks, Journal of Chemical Technology and Biotechnology, 51 (1): 97-103.

[126]. Padmini, E and Sridhar, S, (2007). Effect of $\mathrm{pH}$ and Contact time on the uptake of heavy metals from industrial effluents by pongamia pinnata bark, Asian Jr. of Microbiol. Biotech. Env. Sc., 9(1): 187-190.

[127]. Pandey, K.B, Singh, V.N and Prasad, G, (19850. Copper (II) removal from aqueous solution by flyash, J, Water Resources, 19: 869-873.

[128]. Patil, S.J, Bhole, A.G and Natarajan, G.S., (2006). Scavenging of Ni (II) metal Ions by Adsorption on PAC and Babhul Bark. Journal of Environ. Science \& Engg. 48(3): 203-208.

[129]. Pehlivana, E, Cetina, S and Yan 1K, B.H, (2006). Equilibrium studies for the sorption of Zinc and Cadmium from aqueous solutions using sugar beet pulp and flyash. Journal of Hazardous Materials, 135 (1-3): 193-199.

[130]. Penasamy, K, Srinivasa, K and Murugan, P. K, (1991). Studies on Chromium (VI) removal by activated groundnut husk carbon, Indian J Environ. Health, 33: 433-439.

[131]. Peraniemi, S, Hannonen, S, Mustalhati, H and Ahlgren, M, (1994). Zirconium-loaded activated charcoal as an adsorbent for arsenic, selenium and mercury, J. Anal. Chem., 349: 510-515.

[132]. Perez Marin, A.B, (2007). Removal of Cadmium from aqueous solutions by adsorption on to Orange waste. J. Hazardous Materials,. B139: 122-131.

[133]. Periasamy K and Namasivayam C., (1996). Removal of Copper (II) by adsorption onto peanut hull carbon from waste and copper plating industry waste water, Chemosphere, 32: 769-789.

[134]. Poots, V.J.P, McKay, G and Healy, J.J, (1976b), Removal of Acid Dye from effluent using naturally occurring adsorbents-Peat and Wood, Wat. Res., 1061-1065.

[135]. Poots, V.J.P, McKay, G and Healy, J.J, (1978), The removal of basic dye from effluent using wood as an adsorbent, J, Wat. Poll. Con. Fed., 50: 926-930. 
[136]. Prabavathi Nagarajan and Priscilla Prabhavathi, (2005). A study of Removal of Pb (II) by adsorption technique using carbonized tamarind seed and seed coats, Indian. J. Environmental protection, 25(5): 433-436.

[137]. Prabhakar, L.D and Palanivel, C, (2003). Optimization of conditions and adsorption isotherm studies of orange TGU on low cost carbon systems, Indian Journal of Environmental protection, 23(12): 1388-1395.

[138]. Pradeep Kumar, Verma.L.K, Sinha S.K. and Bishnu Deo, (2008). Removal of Color from Nigrosin dye effluent using Petroleum based carbon, J. The Ecoscan, 2(1): 35-40.

[139]. Prasad, A. and Sarveswara Rao, (2009), Removal of copper using Micro size coconut Husk powder, Equilibrium and Kinetic studies, J. Nat. Env and Poll. Tech, 8(2): 389-394.

[140]. Pravin, D Nemade, Kadam, A.M and Shankar, H.S, (2009). Adsorption of arsenic from aqueous solution on naturally available red soil, J. Environ. Biol., 30(4): 499-504.

[141]. Priscilla Prabhavathi, S, Shamala rajam, P, Sivapriya, S and Vijayaraj, R, (2011). A comparative study of the adsorption capacities of the adsorbents Rice husk and activated alumina in the removal of the dye-Rhodamine B using adsorption technique, Indian Journal of Environmental protection, 31(10): 819-824.

[142]. Quck, S.Y, Ware, D.A.J and Foster, C.F, (1998). The use of sago waste for the sorption lead and copper. Water SA, 24 (3): 251256.

[143]. Rahman, M.M and Yusof, A.M. (2011). Preparation and Modification of activated carbon from oil-palm shell and its adsorption capacity through speciation of chromium, Res. J. Chem. Environ. 15(4): 49-51.

[144]. Rajachandrasekar, T, Kalaichelvan, G, Hema, M, and Arivoli, S, (2008). Kinetic, thermodynamic and Equilibrium studies of Iron adsorption on a low cost carbonaceous adsorbent, 18(4): 301-312.

[145]. Rajeshwari, Sivaraj, C, Namasivayam and Kadirvelu, K, (2000). Orange peel as an adsorbent in the removal of acid Violet 17 (acid dye) from aqueous solutions. Waste Management, $\mathrm{pp}$ 1-6.

[146]. Raju, P and Saseetharan, M.K, (2008). Removal of Nickel (II) using sludge based low cost activated carbon as adsorbent, Indian Journal of Environmental protection, 28(3): 227-232.

[147]. Raju, P and Saseetharan M.K, (2010). worked on Removal of lead (II) from metal plating Effluents using sludge based activated carbon as adsorbent. J. Environ. Science \& Engg. 52(1): 7-10.

[148]. Raman Kumar, Namita Singh and Narender Kumar, (2011). Biosorption of Lead and Mercury by using four Indigenous fungal species, Indian J. of Environmental Protection, 31(4): 327-331.

[149]. Rampure, P.R and Patil, P.V, (1996). Use of Modified Dhoda Bark for scavenging Cd (II) ion from industrial waste, J. of industrial pollution control, 12(1): 35-49.

[150]. Rampure, P.R and Patil, P.V, (1995).Use of Pulsa bark substrate for recovery of $\mathrm{Cu}, \mathrm{Pb}, \mathrm{Zn}$, Ni from waste water, J. of Industrial pollution control, 4(1,2): 105-109.

[151]. Rao, M, Parwate, A.V and Bhole, A.G., (2003). Heavy metals Removal by Adsorption using Bagasse and Modification to Helfferich Model, J. Environ. Pollu. Control. Journal, 6(4): 6-13.

[152]. Renganathan, S, Sangeetha, K, Dharmendira Kumar, M and Velan, M, (2010). Biosorption of Chromium (VI) from an Aqueous solution using Adothoda Vasica, Indian J. of Environmental protection, 30(1): 46-51.

[153]. Renganathan, S, Shankar, K, Dharmendra Kumar, M and Velan, M, (2008), Biosorption of Congo red dye using Tamarindus Indica fruit shell. Batch studies, Indian Journal of Environmental protection, 28(11): 1028-1033.

[154]. Renugadevi, N, Kavitha, B and Sangeetha, M, (2010), Removal of Methylene blue using a low cost activated carbon from Cassia siamea by adsorption technique, Indian Journal of Environmental protection, 30(1): 52-57.

[155]. Renugadevi, N, Sharfunisha, M and Lalitha, P, (2011). Adsorption of Malachite green using a low -cost activated carbon prepared from cassia fistula, Indian Journal of Environmental protection, 31(7): 569-575.

[156]. Renugadevi, N, Sreeja, M and Lalitha, P, 2010. Adsorption of chromium (VI) from aqueous solution using activated carbon from the pods of wood apple, Indian Journal of Environmental protection, 30(1): 67-73.

[157]. Renugadevi, N, Sumithra, R and Lalitha, P, (2011). Kinetic modelling of adsorption of Malachite green using a low cost activated carbon obtained from caesalpinia pulcherrima, J, Indian Journal of Environmental protection, 31 (10): 850-854.

[158]. Renugadevi, N.B, Archana and Sreeja, M, (2008). Conversion of the rind of Crescentia cujeta into an effective adsorbent for the removal of $\mathrm{Cr}$ (VI) from aqueous solution. Indian J. Env. Prot., 28 (6), 540-546.

[159]. Revathi M, Kavitha B and Vasudevan T,( 2005). Removal of Nickel ions from Industrial plating effluents using Activated Alumina as adsorbent, Journal of Environ Science \& Engg., 47(1):1-6.

[160]. Rosaline Vimala, J, Amala Fatima Rani, Deepa, T and Girija, A, (2011). Removal of Mercury from aqueous solution using castor seed shell carbon- A comparative study, Indian Journal of Environmental protection, 31(10): 842-849.

[161]. Sabriye Doynrum and Ali celic, (2006). Pb (II) and Cd (II) removal from aqueous solutions by olive cake J. Hazardous Material, B137: 626-636.

[162]. Saeed A, Iqbal M and Akhtar M.W, (2005), Removal and recovery of lead (II) from Single and Multimetal (Cd, Cu, Ni, Zn) solutions by crops milling waste (black gram husk), Journal of Hazardous Materials, 117(1): 65-73.

[163]. Sanjeev K. Katyal, Kailash Daga and Sangeetha Loonker, (2003). Dye removal by low cost adsorbent prepared from prosopis cineraria of Thar Desert, J. Poll. Res, , 22(1): 61-64.

[164]. Santhalakshmi S, Gayathri M \& Sudha P.N, (2008). Study on removal of Chromium (VI) from aqueous solution using sulphonated Black Rice husk ash and Sulphonated white Rice husk ash, J. Nat. Env. \& Poll. Tech., 7(4): 733-736.

[165]. Sarita Yadav, Tyagi D.K and Yadav O.P, (2011). Equilibrium and Kinetic studies on adsorption of Congo-red dye from aqueous solution onto rice husk carbon, J. Nat. Env. And Poll. Tech., 10(4): 551-558.

[166]. Sarnaik S and Kanekar P. (1999). Biodegradation of Methyl Violet by pseudomonas mendocina. MCM. B-402. Appl. Microbiol. Biotechnol., 52: 251-254.

[167]. Satapathy D, Natarajan G.S and Khope R.U,( 2004). Separation of copper and zinc in aqueous solutions using modified granular activated carbon, Indian Journal of Environmental protection, 24(11): 838-844.

[168]. Senthikumar S., Varadarajaan P.R, Porkadi K, Subbhuraam C.V. (2005). Adsorption of methylene blue onto jute fibre carbon: Kinetics and equilibrium studies. J. Colloid Interf. Sci., 284: 78-82.

[169]. Senthil Nathan U and Issac soloman Jebamani, M, (2005). Adsorption batch studies on Nickel (II) Removal using wood of Hybrid Eucalyptus Based Activated Carbon, J. Nat. Environ. Pollu. Techn, 4(4): 533-536.

[170]. Shalini Menon, (2000). Sorption removal of procion orange M2R from aqueous solutions using pseudomonas Species. S5 and Aspergillus flavus, M.Sc. Dissertation, Bharathiar University, Coimbatore.

[171]. Sharma J.K, Kaushik C.P and Namrata Kaushik, (2005). Low cost Adsorbents in decolorization of effluents from dying of cotton fabric with Congo Red and Chryosophenine-G, Indian Journal of Environmental protection, 25(1): 61-65. 
[172]. Shashikant R. Misc and Rajamanya V.S,(2003). Sorption studies of Cr (VI) on activated carbon derived from sorghum vulgare (dried stem of jowar), Indian J. Env. Health, 45(1): 49-58.

[173]. Sheth K.N and Umrigar F.S, (2006). Transport mechanism of cadmium using CCAC as Adsorbent, J.Poll. Res, 25(3): $481-484$.

[174]. Sheth K.N and Viral M. Soni, (2004). Comparative study of removal of Cr (VI) with PAC, GAC and adsorbent prepared from tobacco stems, Journal of Industrial pollution control, 20(1): 45-52.

[175]. Shrihari S and Raghavendra Kiran S, (2003). Adsorption of dissolved Iron on Laterite, J. Poll Res., 22(4): 507-510.

[176]. Shrivastava A.K, (2010). Sorption of Zinc (II) on to point of use granular activated carbon from coke (POU-GACFC) Impregnated with waste tea leaves carbons (WTAC) from water/waste $\mathrm{H}_{2} \mathrm{O}$, Indian Journal of Environmental protection, 30(1): $34-39$.

[177]. Singh D.K and Lal J. (1992). Removal of Cr (VI) from aqueous solution using waste tea leave carbon. Indian J. Env. Health,.34: $108-113$.

[178]. Singh D.K., Kavitha and Rastogi, (2004). Adsorptive removal of basic dyes from aqueous phase on to activated carbon of used tea leaves: A Kinetic and Thermodynamic study, J. Environ. Science and Engg. 46(04): 293-302.

[179]. Singh K.K, Singh N.L and Hasan S.H, (2004). Detoxification of copper bearing effluents using low cost Biosorbent Maize Bran, Indian Journal of Environmental protection, 24(5): 345-352.

[180]. Sivamani S and Prince Immanuel V, (2008). Batch adsorption studies for chromium removal, Journal of Environ. Science \& Engg. 50(1): 11-16.

[181]. Sneha Narvekar and Varsha K. Vaidya, (2008). Biosorption of Chromium (VI) by Aspergillus Niger: Kinetic Modelling and uptake parameters. 28 (4): 296-306.

[182]. Sonawane G.H and Shrivastava V.S, (2009). Removal of Basic dye (Methylene blue) from aqueous solution by adsorption using Musa Paradisica: a agricultural waste, Journal of Environ., Science \& Engg., 45-52.

[183]. Sonawane G.H. and Shrivastava V.S, (2008). Adsorption Kinetics for the removal of Malachite green from aqueous solution by using Banana laves, J. Poll. Res. 27(2): 339-33.

[184]. Sophie Beulah S and Muthukumar K, (2010). Chromium (VI) sorption and recovery by chemically activated high temperature Syzygium Jambolanum Nut carbon by column studies, Indian Journal of Environmental protection, 30(1): 62-66.

[185]. Srinivasalu A, Sundaram E.V and Komal Reddy M., (1998). Removal of Cu (II) from Streculia futida L. fruit shell. Indian J. Env. Prot. 18 (9): 687-693.

[186]. Srinivasan K and Hema M, (2009). Removal of Ni (II) from plating waste water by activated carbon developed from Neem oil cake, Indian Journal of Environmental protection, 29(6): 488-498.

[187]. Srinivasan K and Ramadevi A, (2005). Removal of lead in aqueous medium by tamarind nut carbon, Indian Journal of Environmental Protection. 25 (5): 421-428.

[188]. Srinivasan K and Saravanan S, (2006). Removal of Ni (II) from water by oil removed coconut residues, Asian J. of chemistry, 17 (3): 1877-1888.

[189]. Srinivasan K, Balasubramanian N and Ramakrishna T.V. (1988). Studies on Chromium Removal by Rice husk Carbon. Indian Journal of Environ. Health, 30(4): 376-387

[190]. Srivastava S.K, Verma N, Das T.B and Rupa Das, (2007). Removal of zinc from waste water by adsorption on fly ash, Indian Journal of Environmental Protection, 27(6): 502-508.

[191]. Srivatsava R.K, (2001). Removal of Chromium (VI) by utilization of bidi leaves Pollution Research, 20 (4): $639-643$.

[192]. Stephen Inbaraj B and Sulochanna, (2004). Carbonised jack fruit peel as an adsorption for the removal of Cd (II) from aqueous solution. Bioresource Technology, 94(1): 49-52.

[193]. Subanandam and Muthu Velagtydham R, (2003). Kinetic studies on adsorption of Methylene blue onto Lignite fly ash, Journal of Industrial pollution Control, 19(2): 311-328.

[194]. Sudha P.N and Clines, (2008). Removal of heavy metal cadmium from Industrial waste water using chitosan coated coconut charcoal, J. Nat. Env. and Poll. Tech., 7(4): 601-604.

[195]. Suguna devi S.R, Sathish Kumar M, Shanthi K, Kadirvelu K and Pattabhi.S, (2002). Removal of direct-T \& Blue-R from aqueous solution onto carbonized sugarcane bagasse waste, Indian Journal of Environmental Protection, 22(5): 500-505.

[196]. Suman Mor, Ravindra and Bishnoi N.R, (2002). Adsorption of chromium using activated baggase carbon as adsorbent, Indian Journal of Environmental protection, 22(5): 564-568.

[197]. Suresh K, Borah M and Jatty S.K, (2009). Adsorption on Nickel by Bentonite clays a comparative study, Journal of Environ Science \& Engg, 51(2): 133-136.

[198]. Syed shabudeen P.S, Venkatesh. R, Kadirvelu K, Joseph V, Thanikal and Pattabhi S, (2006). Utilization of Kapok hull activated carbon for removal of basic Nile blue dye from aqueous solution, J. Nat. Enviorn. Pollu. Techn., 5(4), $493-504$.

[199]. Tan I.A.W. Hameed B.H. and Ahmad A.L. (2007). Equilibrium and kinetic studies on basic dye adsorption by oil palm fibre activated carbon. Chem. Eng. J, 127: 111-119.

[200]. Tatarto M and Bumpus J.A. (1998). Biodegradation of Congo red by phanerochaetae chrysporium, Waste Resources, 32: 17131717.

[201]. Tee T.W and Khan R.M. (1988). Removal of lead, Cadmium and Zinc by tea waste leaves. Environ. Technology. Lett., 9: 12231227.

[202]. Thamilarasu P and Karunakaran K, (2011). Removal of Nickel (II) from aqueous solution by adsorption onto Ricinus communis seed shell Activated carbons, J. Environ. Science \& Engg., 53(1): 7-14.

[203]. Theivarasu C, Mylsamy S and Siva Kumar N, (2011). Studies on the removal of reactive orange 16 from aqueous solution using cocoa shell carbon as an adsorbent, J. Indian Journal of Environmental protection, 31(7): 588-594.

[204]. Tsai W.T. Chang C.Y, Lin. M.C. Chien S.F, Sun H.F and Hsieh M.F, (2001). Adsorption of acid dye onto activated carbons prepared from agricultural waste bagasse by $\mathrm{ZnCl}_{2}$ activation, Chemosphere, . 45: 51-58.

[205]. Uluozlu O.D, Sari A. Tuzen M and Soylak M, (2008). Biosorption of Pb (II) and Cr (III) from aqueous solution by lichen (parmelina tiliaceae) biomass. Bioresour. Technol.,. 99(8): 2972-2980.

[206]. Umesh K Garg, Satnam Singh, Kaur M.Pand Dhiraj sud, (2007). Removal of Ni(II) ions from Aqueous solutions by sugarcane Bagasse, Pollu. Res. 26(1): 59-62.

[207]. Valix N and Syna N, (2002). Assessing the potential of activated bagasse as gold adsorbent for gold-thiourea, Water Research, 37(16): 4038-4044.

[208]. Varsha K Vaidya and Ati S Anand, (2009). Decolorization of Reactive Black 5 dye by a white rot fungi Trametes versicolor, J. Nat. Environ. \& Pollu. Tech., 8(4): 701-708.

[209]. Vasanth kumar K and Bhagavanulu V.S, (2003). Adsorption of Basic dye from its aqueous solution onto Bio-organic waste (Part-1, External mass transfer studies), Journal of Industrial pollution control,. 19(1): 20-28. 
[210]. Vasanthy M and Sangeetha M, (2006). Effective heavy metal (Chromium) Removal using low cost adsorbent Prosopis Spicigera, J.Ecotoxicol. Environ. Monit. 16 (3): 251-257.

[211]. Vasanthy M, Geetha A and Seethadevi G, (2008). Removal of a Reactive dye (Red RB) by the Bacterial species Isolated from dyeing Industry effluents, J Nature Environment Pollution Technology, 7(4): 683-686.

[212]. Vasanthy M, (1996). Removal of reactive dyes from aqueous solutions and dyeing industry effluent by Cashew nut hull carbon. Ph.D. Thesis, Bharathiar University, Coimbatore.

[213]. Vasanthy M, Sangeetha M and Kavitha C, (2003). Solutions using a mixture of fly ash and activated carbon, J. Indian Journal of Environmental protection, 23(12): 1321-1325.

[214]. Verma V.R and Mishra A.K, (2005). Dye removal by saw dust based adsorbent, J. Poll. Res, 24(1): 97-99.

[215]. Vijaya Kumari N and Srinivasan K, (2007). Adsorption of mercury (II) from aqueous solution by coconut oilcake residue carbon, Indian Journal of Environmental protection, 27(9): 799-807.

[216]. Vijeta Gupta, Radha Gupta, Shalini Vashishtha and Singh R.P, (2009). Removal of cadmium by modified Bagasse Dust and fly ash, J. Ecotoxicol. Environ. Monit, 19 (1): 79-83.

[217]. Yasin Yamin, Malek Abd Hafiz Abd, Sumari siti Mariam and Ahmad Faujan B.H, (2010. Removal of Amido Black dye from aqueous solution uncalcined and calcined Hydrotalcite, Res. J. chem. Environ, 14(1): 78-84.

[218]. Yatome C, Ogawa T and Matsure M, (1991). Degradation of Crystal Violet by Bacillus subtillis. J. Environ. Sci. Health, 826: 7587.

[219]. Yesilda O and Ozcan B. (1998). Decolorization of orange 11 dye with the crude culture filtrate of white rot fungus, Coriolus Versicolor, Tr. J. Biol., 22: 463-476.

[220]. Yoshio N, Kenji T and Toshiro T, (2001). Adsorption mechanism of hexavalent chromium by redox within condensed tannin gel, J of water research, 35 (02): 496-500. 